\title{
Evaluation of Green Elements and Thermal Comfort Condition of Assyafaah Mosque, Singapore
}

\author{
Noor Muhammad Abd Rahman ${ }^{\mathrm{a}}$, Muhammad Syukri Imran Abdullah ${ }^{\mathrm{b}, *}$ and Chin Haw Lim ${ }^{\mathrm{a}}$ \\ ${ }^{a}$ Solar Energy Research Institute, University Kebangsaan Malaysia, Bangi, 43600, Selangor, \\ Malaysia \\ ${ }^{b}$ The Institution of Engineers Malaysia, Bangunan Ingenieur, Petaling Jaya, 46200,Malaysia
}

\begin{abstract}
A mosque is a place for worship and religious activities that are traditionally built with a typical design and shape with a dome and minaret as its traditional symbols. The most basic design of a mosque is a simple single-storey rectangular-shaped building with a prayer hall inside it. Design in the past was influenced by social and cultural aspects. However, regional and climatic differences have led to thermal discomfort and unnecessary energy use if the mosque is not properly designed. Therefore, there is a need to consider comprehensive planning and review for passive design to avoid thermal discomfort and excessive use of energy. Assyafaah Mosque in Singapore is one example that considers sustainable elements in its design. While Singapore is located very near to the hot equatorial line, many passive and green features have been integrated into the design and construction of the mosque, and this made it possible to achieve an acceptable thermal condition according to the adaptive and PMV thermal comfort model. The design maximizes the potential of naturally ventilated design with other passive strategies which allow for both thermal comfort and energy saving. This paper aims to study the impact of natural ventilation and other passive design decisions on the thermal comfort of the Assyafaah mosque in a hot and humid climate.
\end{abstract}

Keywords: Ventilation, Thermal comfort, Modern mosque, Tropical climate, Adaptive thermal comfort

\section{Introduction}

Many of us spend most of our time inside a building. A study revealed that $90 \%$ of the time is spent indoors for working, studying and other activities [1]. While an unprecedented amount of time indoors will contribute to health problems, thermal comfort is also a serious concern to the building occupants. A good thermal comfort not only enables greater work productivity but also helps the occupants to satisfy themselves physiologically and psychologically in their daily life. Furthermore, mosques can act as a focal point and landmark especially if located in urban areas which will host many public activities [2]. Many pieces of literature relate thermal comfort with energy efficiency in buildings. Although thermal comfort is given higher priority when designing a building, energy efficiency strategies should assist the designer to optimise building performance. Therefore, good architecture and passive design will play a major role in ensuring the objectives are realised. One way

\footnotetext{
* Corresponding author.

E-mail address: simran800102@gmail.com

Manuscript History:

Received 28 May, 2021, Revised 5 September, 2021, Accepted 6 September, 2021, Published 31 October, 2021

Copyright (C) 2021 UNIMAS Publisher. This is an open access article under the CC BY-NC-SA 4.0 license.

https://doi.org/10.33736/jaspe.3434.2021
}

e-ISSN: 2289-7771 
to achieve energy saving without compromising on thermal comfort is to work with natural ventilation of the building.

Thermal comfort can also be defined as a state of mind which expresses thermal acceptability within the environment [3]. Because individuals are different, it is impossible to satisfy everyone's thermal comfort. The differences in human thermal satisfaction can be influenced by many factors. Apart from physiological and psychological factors, the indoor air quality inside the building, nature of work or activity, and outdoor environment can also affect the individuals. Mosques and hospitals are two examples that can give a dissimilar output of thermal expression. While people in mosques require a more relaxing surrounding to attain the feeling of tranquillity, patients and staff in hospitals need to tolerate the thermal discomfort depending on their health and working conditions respectively.

Muslims use the mosque as a place for worship and religious activities. Normally, the building is built with a typical design and shape with a dome and minaret as traditional symbols of a mosque. The most basic design of a mosque is a simple single-storey rectangular building with a prayer hall inside it. Haraty and Utaberta (2019) discovered that mosque design in the past was influenced by social and cultural aspects. However, Aziz, (2016) in his research suggested the urgent need for a green and sustainable design incorporated into mosques. This finding is very important because regional and climatic differences can lead to thermal discomfort and unnecessary energy use if the mosque is not properly designed. Assyafaah Mosque in Singapore is one example that considers sustainable elements in its design. The modern and contemporary architectural design of the mosque has received multiple awards locally and internationally. The architect applied passive strategies in the design including natural ventilation to achieve thermal comfort and energy conservation. This paper reports the impact of natural ventilation performance on thermal comfort in the main prayer hall of Assyafaah mosque in a tropical climate.

Many papers concluded that building occupants of the naturally ventilated building are satisfied and more tolerant of their thermal environment when encountering high temperatures [6], [7] \& [8]. It is supported by Saeed, (1996) when the result of his survey found that worshippers performing Friday prayers in Riyadh felt comfortable despite the hot weather. Good thermal condition in the naturally ventilated building will improve the overall thermal acceptability of the occupant [10]. In addition, natural ventilation is a preference for people inside the building compared to an airconditioning system when both systems become an option [11]. Ji et al., (2006) did a field study to examine naturally ventilated conditions in Shanghai, China. The study concluded that people who live in a hot climate are better equipped to tolerate climate changes and are able to adapt to thermal sensations. Therefore, natural ventilation needs to be carefully designed for people to feel peaceful, comfortable and serene in performing their activities [13]. Unfortunately, Ibrahim et al., (2014) and Bakhlah and Hassan, (2012) reported in their research that adequate comfort to the building occupants and indoor air quality problems have not been comprehensively studied.

A good passive design is not only important for thermal comfort but also a key to be an energyefficient building. Al-Homoud et al. (2009) found that thermal comfort conditions in a mosque filled with people in a hot and humid climate are not easy to maintain due to operational and design reasons. He also suggested operational zoning could be considered and implemented in the mosque's design stage to maintain thermal satisfaction. Energy can also be saved by identifying which areas are usually fully occupied, and which areas are only intermittently used by worshippers. In previous studies, many researchers tried to explore and investigate ways to save energy without compromising comfort. Al Anzi \& Al-Shammeri (2010) have studied the possible energy opportunities for mosques in Kuwait using the simulation model and proposed improvement of building envelope and operating strategies to achieve up to $72 \%$ energy saving. In the same paper, they also found that an energy saving of around $40 \%$ using life-cycle cost assessment was possible with a simple payback period of fewer than 4 years. The exterior envelope can also be a major influence on a building's energy and thermal performance [17]. Thus, comprehensive planning and review for passive design need to be greatly considered to avoid thermal discomfort and excessive use of energy. In addition, the design 
should also integrate automation and technology to control the behaviour of occupants and to ensure the building is capable to adapt to the local climate. Proper naturally ventilated design for buildings may offer the best option for both thermal comfort and energy saving but detailed study must be done to suit the local weather condition.

\subsection{Contemporary mosque designs trend}

Generally, previously built mosques in past decades can be described as environmentally sustainable due to the vernacular style in construction and materials used [18]. Most of the designs emulated the famous Islamic civilizations in terms of layouts and structures. They represent the glory, power and grandeur of Islamic architectural art [19]. Aziz (2016) reviewed Cyberjaya Mosque in Malaysia as a green and sustainable design with a layout that is well adapted to a hot and humid climate. The mosque not only uses modern materials but also provides excellent cooling strategies to reduce the building's overall cooling load. The mosque central courtyard allows for natural ventilation while the hot air in the main prayer hall is released through the openings or ventilators located in its glass dome structure as shown in Figure 1. Therefore, no air conditioning and lighting is required during the daytime. The use of artificial turf which also doubles up as rainwater harvesting catchment area and solar photovoltaics (PV) over the concrete roof top further reduce the heat gain and contribute to low indoor temperature.

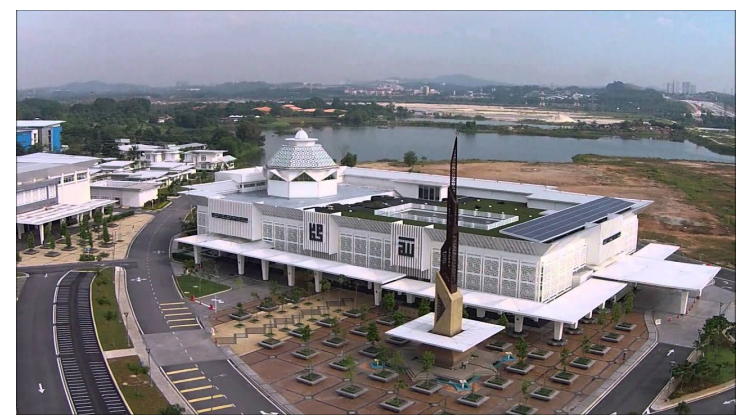

(a)

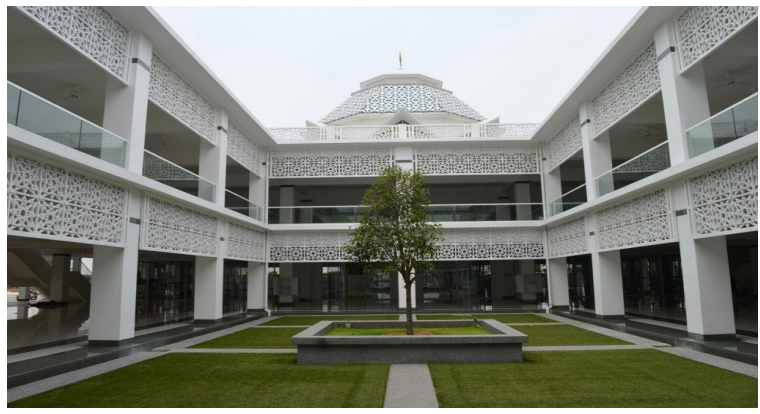

(b)

Figure 1. Modern mosque in Cyberjaya with passive cooling and lighting strategies; (a) double glazing glass dome at roof level and (b) central courtyard for cross ventilation and daylighting.

Another modern mosque which is located in Putrajaya, Malaysia also presents some passive design features in the building architecture. About $70 \%$ of the mosque was built using steel structure and based on the open-air no wall concept allowing for natural ventilation through its stainless steel mesh on all sides. The side perimeter pool surrounding the main prayer hall and the Putrajaya lake adjacent to it provides more effective cooling and a comfortable indoor environment (Figure 2). This important feature offsets significant energy use for cooling purposes. 


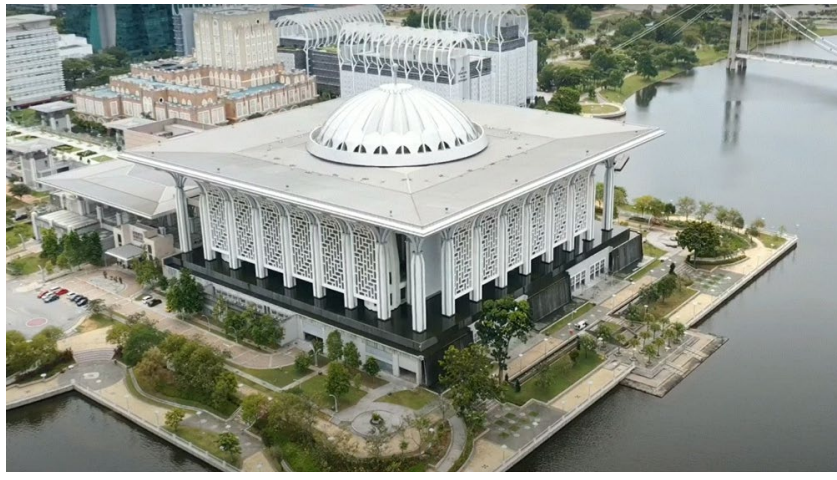

(a)

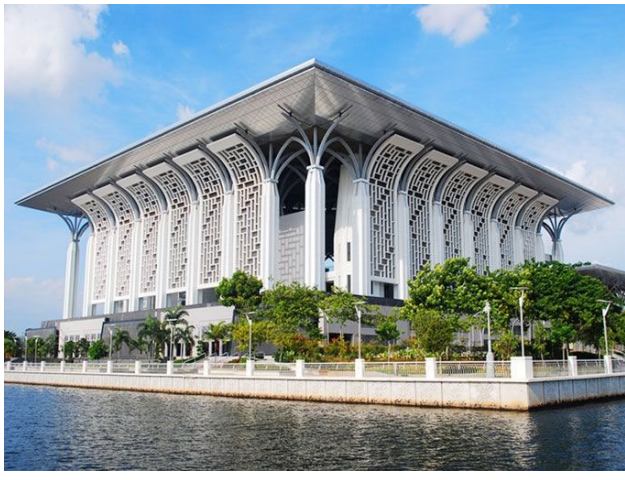

(b)

Figure 2. Tuanku Mizan Zainal Abidin Mosque in Putrajaya, Malaysia; (a) main prayer hall surrounded by mosque perimeter pool and the building itself surrounded by a lake and (b) stainless steel mesh as shading façade and natural ventilation.

In terms of energy efficiency, Khalifa Al Tajer Mosque in Dubai was designed in such a way that utilises solar energy to power lighting, an efficient thermal insulation system and low energy air conditioning (Figure 3). The mosque has also implemented separate zoning to differentiate areas by functionality to reduce energy usage while providing thermal comfort [20]. Other energy-efficient features include energy-saving LED lamps with daylight sensors as well as a smart climate control system that regulates the air-conditioning units according to prayer times and the number of worshippers. Another outstanding eco-design mosque can be seen in Cambridge, England which integrates a lot of sustainable design decisions to be an environmentally friendly mosque [21]. Some features in the design include large skylights, low energy LED lamps, PV cells located on the roof that is very well insulated and naturally ventilated, and having locally generated energy that provides cooling and heating for the mosque. Apart from the environmental principles in the design of the mosque, an Islamic garden is also an integral part of the mosque which provides a green space of biodiversified, insect friendly and sustainable plantings (Figure 4).

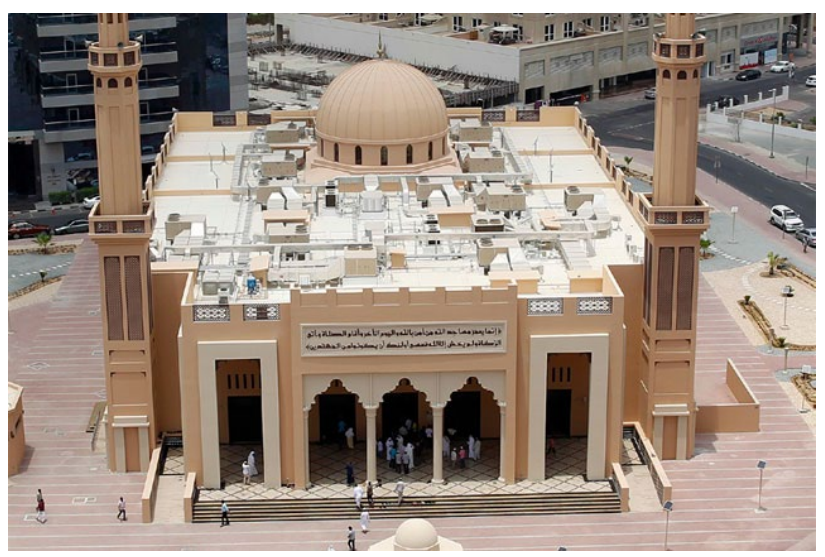

Figure 3. Khalifa Al Tajer Mosque in Dubai opened as an eco-friendly and smart mosque in the year 2014. 


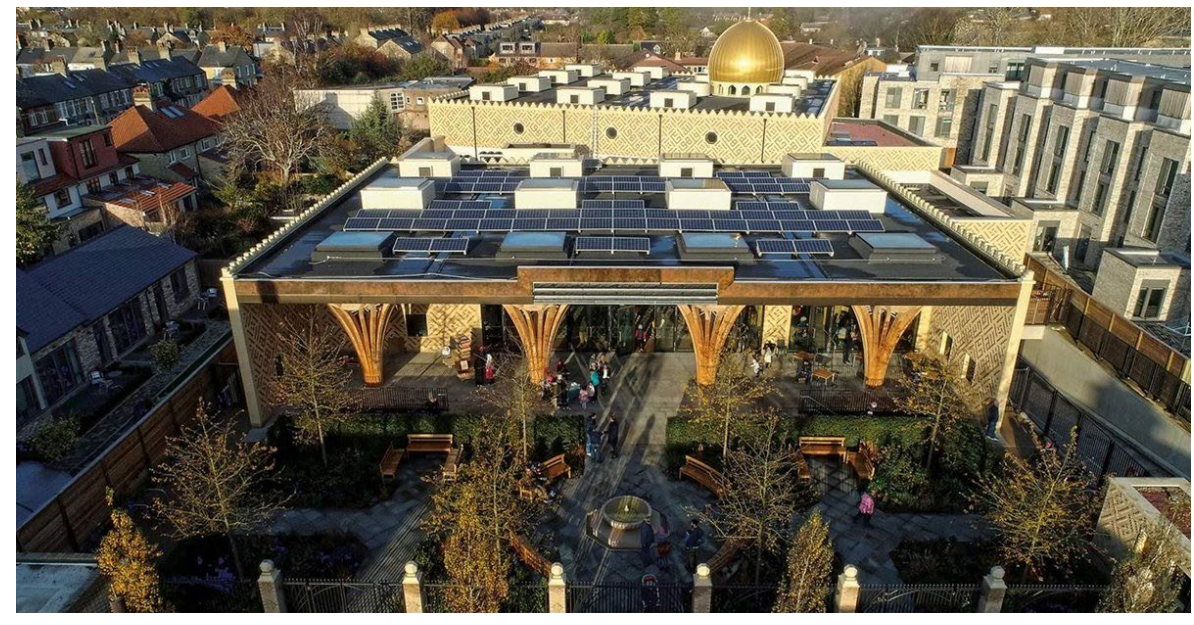

Figure 4. A British mosque for the $21^{\text {st }}$ century with an environmental design principle that includes a skylight and solar PV on the roof.

There is a significant improvement in environmental awareness throughout the world with many countries having their policies on sustainable design. Morocco had pledged to develop 600 mosques by 2019 with a green design concept and struck a partnership with Germany to execute the plan [22]. The project had been predicted to contribute $40 \%$ energy saving compared to the conventional mosque design by combining passive and active strategies to the buildings. Indonesia is another country that planned to build eco-mosques due to climate change issues. With the majority of its population being Muslims, Indonesia had unveiled their plan to construct 1000 mosques with green and sustainable elements by 2020 to set a good example in the Asian region [23].

Based on the above reviews, most of the sustainable and green designs aimed to achieve low energy mosques while meeting the thermal satisfaction of building occupants. However, commonly used combine natural ventilation with mechanical fans in mosques in Malaysia are not always able to meet the desired thermal condition. Noman et al., (2016) reported in their study that predicted mean vote (PMV) and predicted percentage of dissatisfied (PPD) values of the investigated mosque in a hot and humid climate is well above the ASHRAE Standard-55. Therefore, proper evaluation and design decisions are crucial in meeting thermal satisfaction during the design and after the construction stage. A study of Singapore's Assyafaah Mosque in this paper aims to review the existing contemporary architecture in this hot and humid climate region and analyse the impact of the design on thermal comfort.

\section{Methodology}

\subsection{Climatic condition}

Singapore is located one-and-a-half degrees north of the equator with a constantly hot and humid climate throughout the year. The city has a daily average temperature ranging from $26^{\circ} \mathrm{C}$ $\left(90^{\circ} \mathrm{F}\right)$ to $32^{\circ} \mathrm{C}\left(79^{\circ} \mathrm{F}\right)$ and daily average relative humidity ranging from $72 \%$ to $87 \%$ [25]. Table 1 shows a daily observation of air temperature and humidity of Singapore from 1st to 10th October 2019. Knowledge of local temperature gave a clear understanding of natural ventilation design potential while relative humidity information indicated how well evaporative cooling would work in a building. A study by Lau et al., (2019) also found that Singapore received relatively high and 
consistent global horizontal irradiance (GHI) of $1671 \mathrm{kWh} / \mathrm{m} 2$ per annum with a monthly average of $139 \mathrm{kWh} / \mathrm{m} 2$. These useful data assisted designers to control heat gain caused by solar radiation.

Other important weather data acquired for passive design strategies were wind speed and wind direction. Wind speed inside the building was measured using a hand-held digital anemometer. The measured data were used to calculate the thermal comfort indices of the mosque. Statistical data of Singapore's wind direction distribution were retrieved from the Windfinder website [27]. The data collected was based on daily observations starting from 2006 until September 2019 between 7 am and $7 \mathrm{pm}$ local time. Winds were prominently blowing from the northeast and the south directions as shown in the wind rose diagram in Figure 5. Generally, winds followed the prevailing monsoon flow except when light winds were being modified by terrain or weather systems [28]. Wind speed and wind direction information were essential for the designers to consider cross-ventilation strategy based on the analysed data available for space cooling or hot air diverting purposes. For this study on Assyafaah Mosque with a prayer hall that depended on natural ventilation, the knowledge on Singapore's weather was important and posed significant challenges to achieve thermal comfort satisfaction.

Table 1. Daily observations of temperature and humidity of Singapore (Weather Underground, 2019)

\begin{tabular}{|c|c|c|c|c|c|c|}
\hline Day & \multicolumn{3}{|c|}{ Temperature $\left({ }^{\circ} \mathbf{F}\right)$} & \multicolumn{3}{c|}{ Humidity (\%) } \\
\hline October & Maximum & Average & Mininimum & Maximum & Average & Mininimum \\
\hline 1 & 90 & 82.6 & 79 & 94 & 77.4 & 58 \\
\hline 2 & 88 & 79.8 & 73 & 100 & 84.7 & 62 \\
\hline 3 & 88 & 80.8 & 75 & 94 & 79.7 & 58 \\
\hline 4 & 88 & 82.5 & 79 & 94 & 78.1 & 55 \\
\hline 5 & 91 & 83.6 & 77 & 89 & 72.1 & 49 \\
\hline 6 & 90 & 82.5 & 77 & 94 & 75.8 & 49 \\
\hline 7 & 90 & 81.1 & 75 & 100 & 85.1 & 59 \\
\hline 8 & 88 & 82.3 & 77 & 100 & 80.8 & 58 \\
\hline 9 & 88 & 82.3 & 79 & 94 & 80.0 & 58 \\
\hline 10 & 91 & 83.7 & 79 & 94 & 75.9 & 55 \\
\hline
\end{tabular}

Wind direction distribution in \%
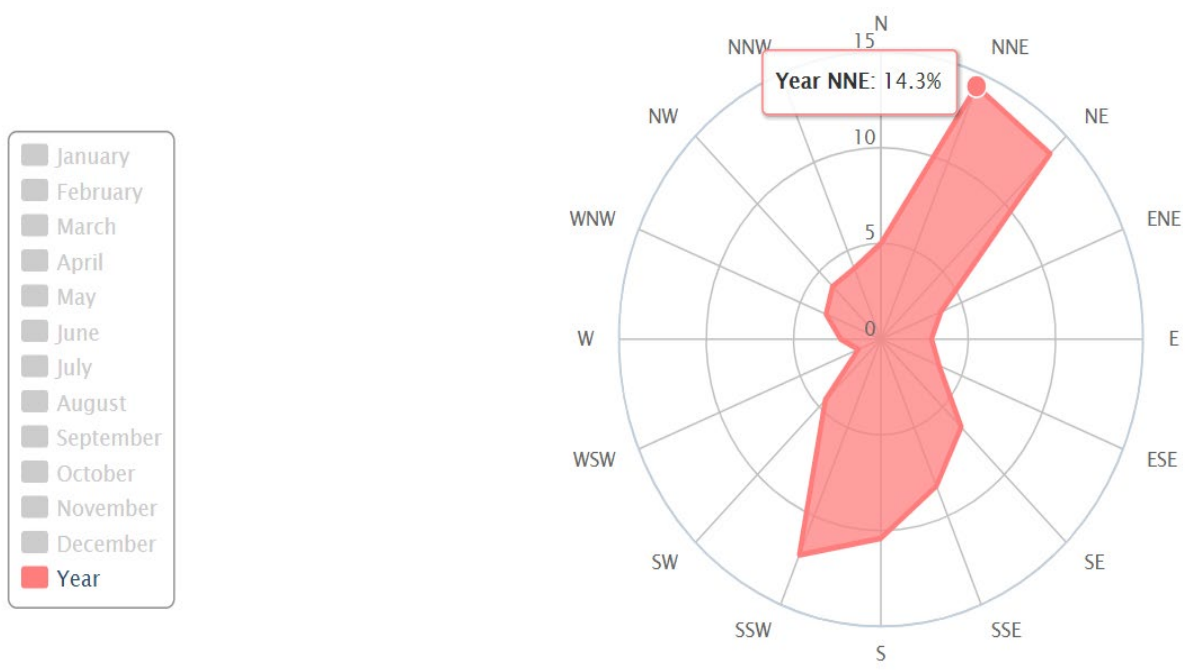

Figure 5. Percentage of wind direction distribution (Windfinder, 2019) 


\subsection{Mosque layout review}

The layout of the Assyafaah Mosque was comprehensively studied to better understand the existing passive design techniques applied to the building. Observation of the mosque's design is discussed in detail in the results and discussion section. The review of the mosque layout focused on the building orientation as well as how the building form and fabric affected the natural ventilation and thermal mass of the building.

\subsection{Measuring equipment}

The equipment and instruments used in this study to record field measurements are listed in Table 2. All these tools were calibrated before use to ensure the reliability of the data measured.

Table 2. List of instrumentation used in the field measurement

\begin{tabular}{|l|l|}
\hline Instrumentation & Type of use \\
\hline Thermal imager & To measure surface temperature in ${ }^{\circ} \mathrm{C}$ \\
\hline Air speed meter & To measure air movement in $\mathrm{m} / \mathrm{s}$ \\
\hline $\begin{array}{c}2 \text { in 1 air temperature and relative } \\
\text { humidity datalogger }\end{array}$ & $\begin{array}{c}\text { To measure and log air temperature in }{ }^{\circ} \mathrm{C} \\
\text { and relative humidity of air in } \%\end{array}$ \\
\hline Laser distance meter & To measure height and distance in $(\mathrm{m})$ \\
\hline
\end{tabular}

\subsection{Measurement of thermal comfort parameter}

Evaluation of thermal comfort in the main prayer hall used Fanger's PMV/PPD thermal comfort model and the adaptive thermal comfort model. While Fanger's PMV-PPD is well accepted for conditioned spaces, ASHRAE 55 introduces the adaptive model for naturally ventilated spaces. This model was applied in this type of space due to the human ability to adjust to their surroundings. The adaptive model is also known as a method that considers three inter-related aspects which are human's psychological, behavioural and physiological aspects [29]. Fanger's PMV/PPD thermal comfort model has identified six (6) primary parameters to define conditions for thermal comfort. The parameters that were measured using the identified instruments were metabolic rate, clothing insulation, air temperature, mean radiant temperature, air speed, and relative humidity.

The adaptive thermal comfort model requires only three (3) parameters compared to Fanger's PMV/PPD model which comprises operative temperature, prevailing mean outdoor temperature and air speed.

\subsection{Thermal comfort indices calculation}

The measured parameters values were used to calculate thermal comfort indices using the thermal comfort tool. Both Fanger's PMV/PPD model and adaptive model results were compared and analyzed for further improvement. Table 3 shows the thermal sensation scale according to ISO 7730 , (2005). 
Table 3. Seven-point thermal sensation scale according to ISO 7730

\begin{tabular}{|c|l|}
\hline+3 & Hot \\
\hline+2 & Warm \\
\hline+1 & Slightly Warm \\
\hline 0 & Neutral \\
\hline-1 & Slightly cool \\
\hline-2 & Cool \\
\hline-3 & Cold \\
\hline
\end{tabular}

\section{Results and Discussion}

\subsection{Green element}

Assyafaah Mosque which was officiated in 2005 is a midrise building with a basement car park. The ground level consists of the main prayer hall and reception plus another 3 upper floors which contain classrooms, an extended praying area for women and men as well as the administration office. The longer side of the building is oriented so that one end faces the kiblah or west. Such orientation minimizes the heat gained from the sun as the relatively smaller surface wall is facing the sun along its sun path. There are no nearby or adjacent buildings that can obstruct the natural airflow in the area, therefore, encouraging cross ventilation in the building.

The building is also located within a wide-open space surrounding which reduces the heat island effect on the building. In terms of construction, the building was primarily constructed from reinforced concrete (RC) including $\mathrm{RC}$ roof slab. The white brick wall gives the ability of the building to reduce the effect of daily heat swing that controls the indoor air temperature of the enclosed area in the building [31]. Apart from that, the roadway within the mosque compound was primarily constructed from block pavement. The use of block paving for motorways reduces water runoff and allows rainwater to seep through the pavement block and into the ground. The partly bright coloured block also helps in reducing the heat island effect. The mosque is a gated community building and the entrance to the building is provided at the main entrance on the east side as shown in Figure 6 and also at its north side as shown in Figure 7. The doorless entryway at the entrance appears to provide cross ventilation primarily for the main prayer hall.

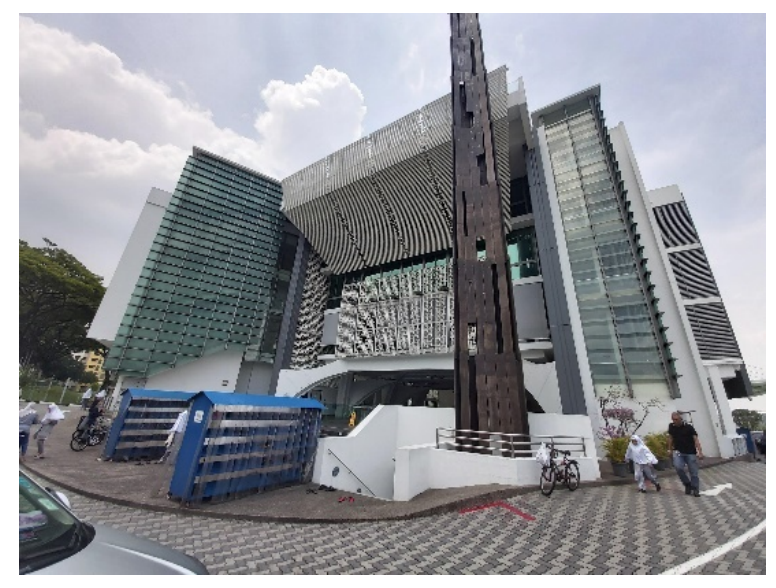

Figure 6. The main entrance of the mosque (facing east/opposite kiblat) 


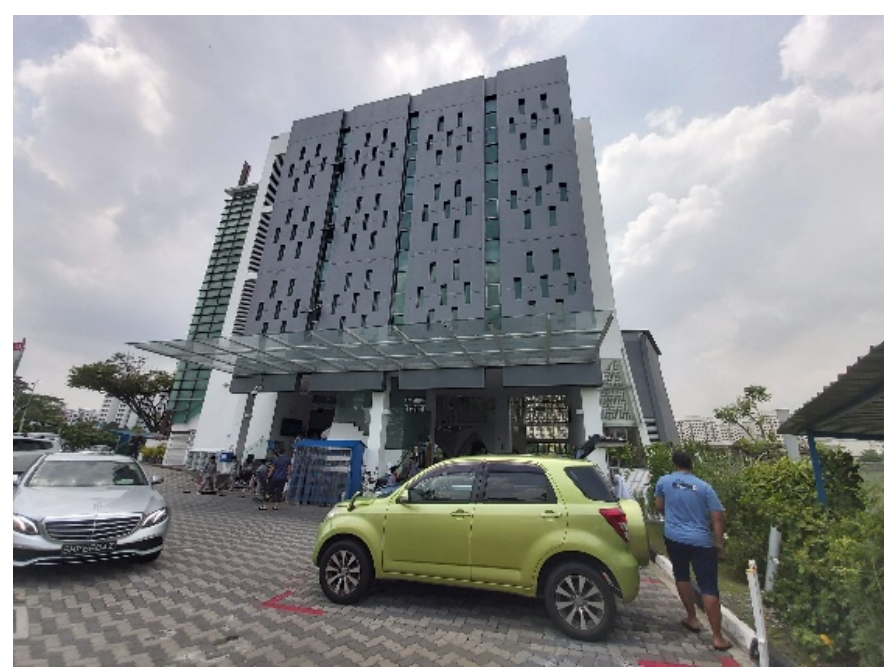

Figure 7. Side entrance of the mosque (facing north)

Arabesque screen panels shown in Figure 8 were fitted at the exterior and the prayer hall area. They help to reduce solar heat gain while allowing daylighting to the main prayer hall as well as the classrooms. Figure 9 shows the opaque building envelope which is facing the kiblah that is a typical brick wall construction. The white wall maintains a high Solar Reflectance Index (SRI) which helps to reduce heat gain through the building envelope. Maintaining high SRI helps to control the heat island effect on the surrounding area.

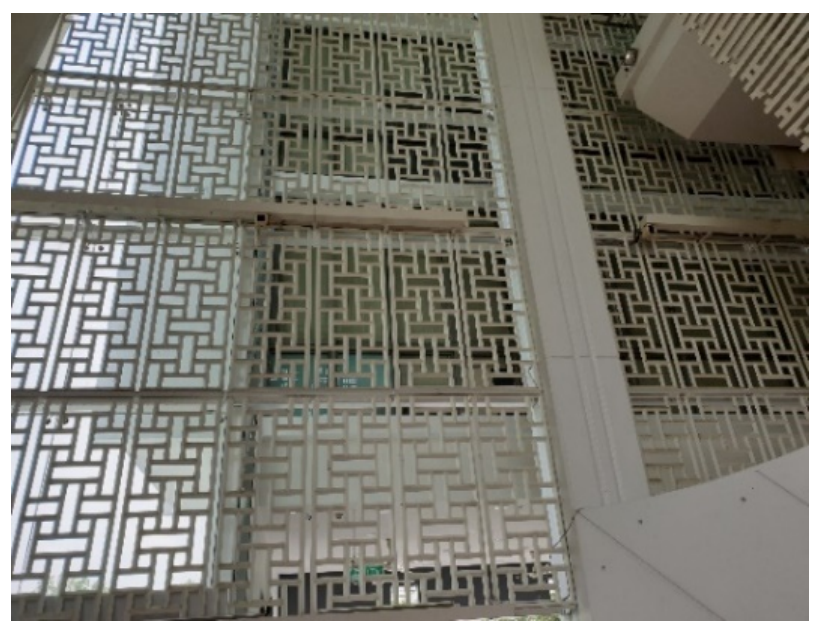

Figure 8. Arabesque screen panels

Minimal fenestration or window structure is facing the east and west sides of the mosque which minimizes the heat gained from the sun. Glass façade with fixed shading is located on the north and south sides of the building as shown in Figure 7 and Figure 10 respectively. Classrooms and general offices are also located on the north and south sides of the building as shown in Figure 11. Windows in those areas have clear glass windows designed with solar shading. Solar shading provides shade and reduces the heat gain from short and longwave radiation but still allows for daylighting in the classrooms. 


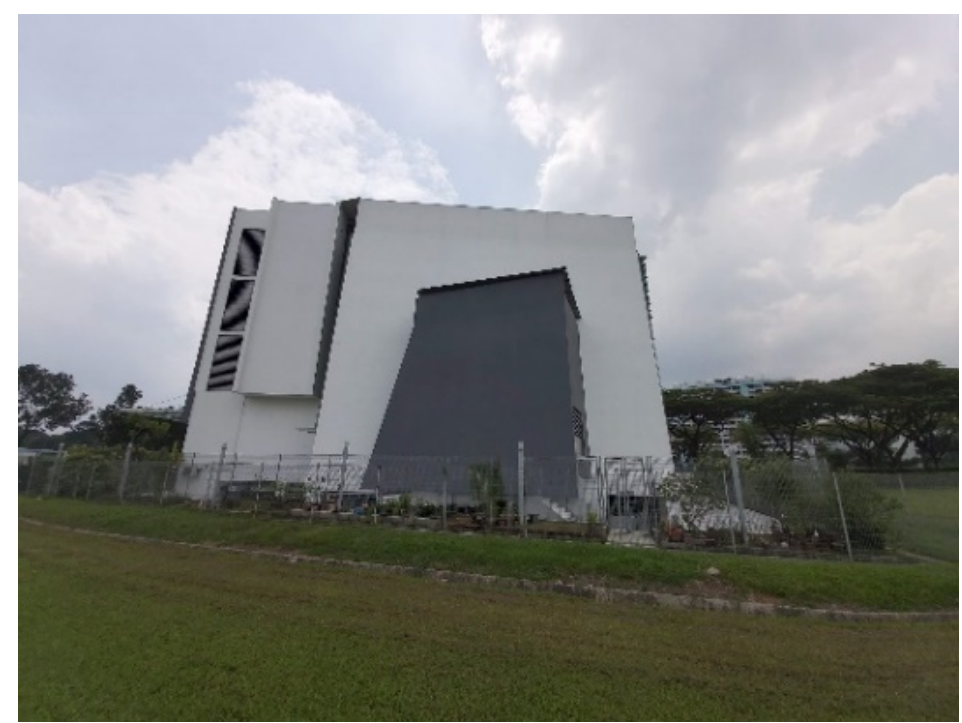

Figure 9. The backside of the mosque (facing west/kiblah)

The design of the mosque also provides sufficient daylighting to the building spaces. Therefore, it relies less on artificial lighting which contributes to lower energy consumption. Usage of LED at night improves efficiency and reduces energy demand. The single-level basement construction is also designed in such a way that allows cross ventilation and cooling effect in the area as the floor is connected to the cool and shaded ground.

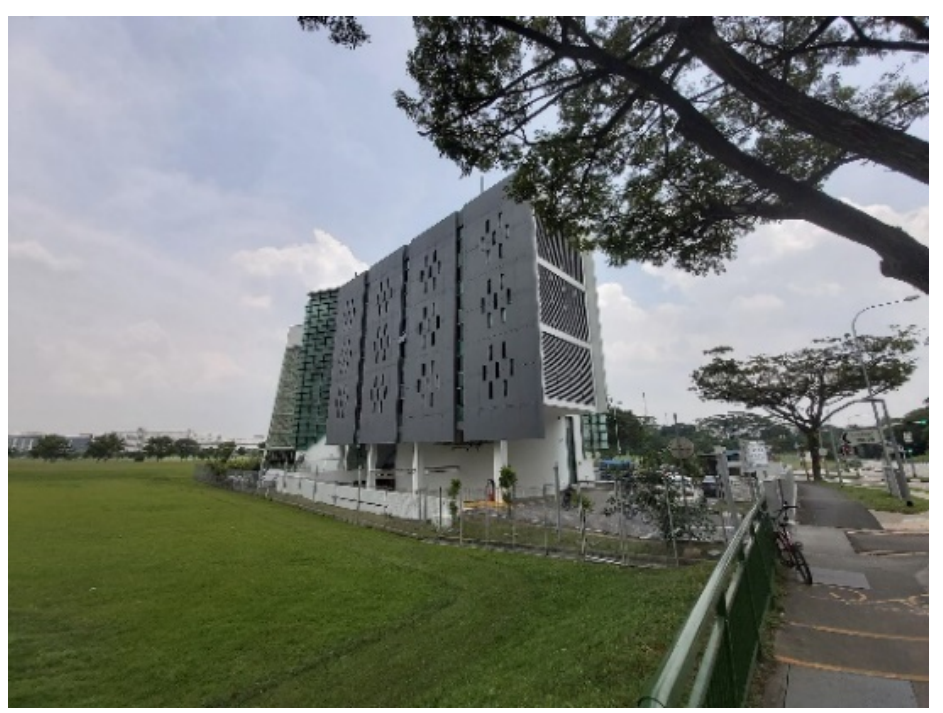

Figure 10. Southside of the building

The main prayer hall is located just above the basement parking. It is designed to allow for natural ventilation that flows freely above and below the main prayer hall floor, therefore, providing a cooling effect in that zone. The doorless and wide opening provided at the main prayer hall level allows free flow of air or cross ventilation which also provides a cooling effect as shown in Figures 12 and 13. 


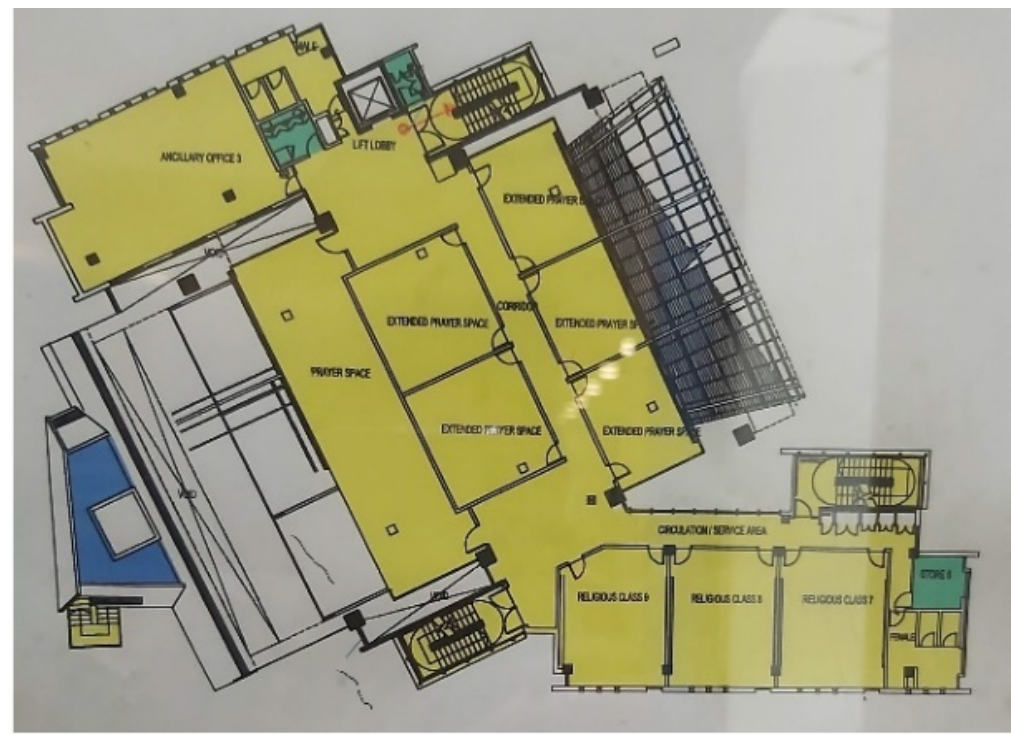

Figure 11. The layout of the building for level 2

There are also several ceiling fans and standing fans located at strategic locations to provide air movement that improves the thermal comfort of the space. A larger industrial fan is also provided in the main prayer hall area for the same purpose. If the water table is not an issue, the prayer hall can be built at a level lower than ground level. The prayer hall floor can be constructed directly above the cool ground. The cooler ground will cool the slab even during the day and this will help to lower the floor temperature. A floor temperature of between $28^{\circ} \mathrm{C}$ and $30^{\circ} \mathrm{C}$ is possible depending on the type and depth of the slab in the ground according to Imran et al., (2017). A summary of green elements and their design objective is listed in Table 4.

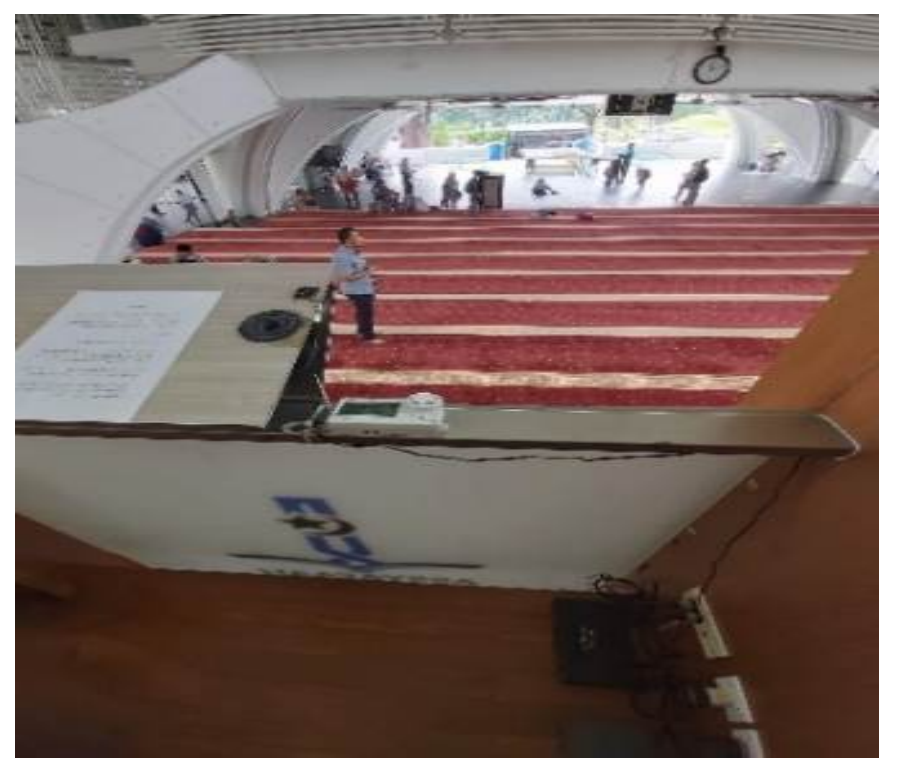

Figure 12. View from mimbar towards the main entrance; entryway connects to the main prayer hall without any wall constructions allows for free airflow movement. 


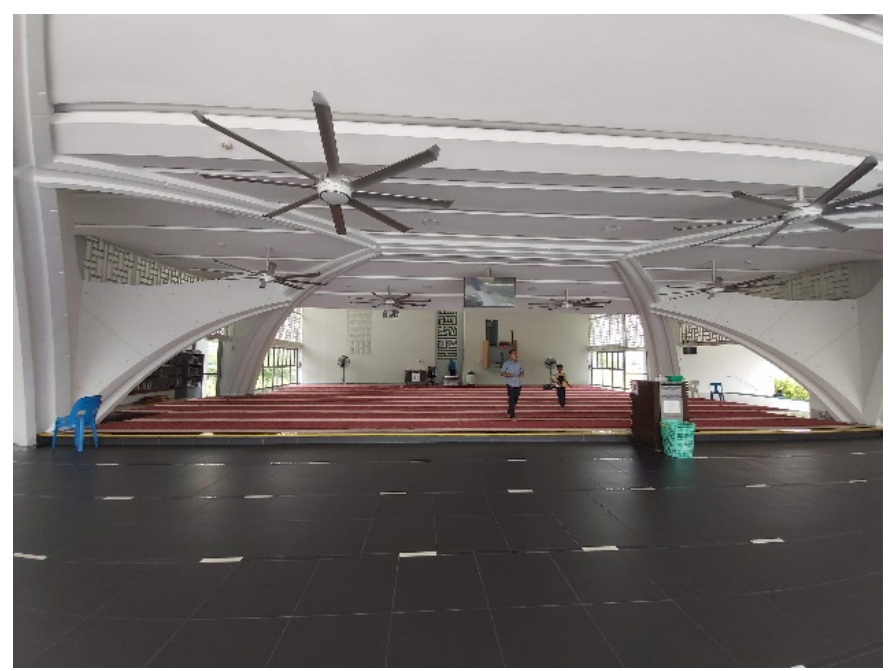

Figure 13. Prayer hall facing kiblah. Lower ceiling equipped with ceiling fan; side entryway connected to prayer hall without wall construction allows for free air movement.

Table 4. Summary of green or passive features that are provided in the design

\begin{tabular}{|l|l|}
\hline \multicolumn{1}{|c|}{ Passive/green Elements } & \multicolumn{1}{c|}{ Objective } \\
\hline $\begin{array}{l}\text { Minimal fenestration or window structure } \\
\text { facing east and west side. }\end{array}$ & Reduce heat gain \\
\hline Fix and wide opening at east and north side & Prevailing wind for natural ventilation \\
\hline Transparent façade & Less reliance on artificial lighting. Low energy use \\
\hline $\begin{array}{l}\text { Usage of LED at night improves efficiency } \\
\text { and lowers energy demand. }\end{array}$ & Energy-efficient building \\
\hline $\begin{array}{l}\text { Basement construction with plenty of cross } \\
\text { ventilation }\end{array}$ & $\begin{array}{l}\text { Natural ventilation flows freely above and below } \\
\text { the main prayer hall floor. }\end{array}$ \\
\hline $\begin{array}{l}\text { Classrooms and general offices have clear } \\
\text { glass windows designed with solar shading. }\end{array}$ & Reduce heat gain while allowing daylight. \\
\hline Occupant control air movement & $\begin{array}{l}\text { Allow acceptable thermal condition with increased } \\
\text { air movement }\end{array}$ \\
\hline Building orientation (longer side facing north) & Reduce solar heat gain \\
\hline Construction in an open space & More air flow and reduced heat island effect \\
\hline Brick wall and RC roof slab and structure & $\begin{array}{l}\text { The reduced indoor diurnal temperature in enclosed } \\
\text { space }\end{array}$ \\
\hline The bright coloured external surface & Reduce heat gain to the building \\
\hline Block pavement & Reduced water runoff \\
\hline
\end{tabular}




\subsection{Thermal comfort condition}

Thermal acceptance of the building was calculated using the CBE thermal comfort tool which complied with ASHRAE Standard 55-2017. Both Fanger's PMV model and the adaptive model calculation are presented in this paper. A thermal imager was used in the site survey to check on the surface temperature of the internal building surfaces which gave a good indication of the radiant temperature of the indoor surfaces in the building. Figure 14 shows the surface temperature of the glass wall and arabesque screen from inside the main prayer hall which was about $34^{\circ} \mathrm{C}$. The temperature was consistent throughout the entire wall facing the outdoor therefore influencing greatly the indoor thermal comfort condition. The higher surface temperature was expected from the glass wall façade as it was made of clear glass material and did not have any application of Low-E radiant layer or coating.

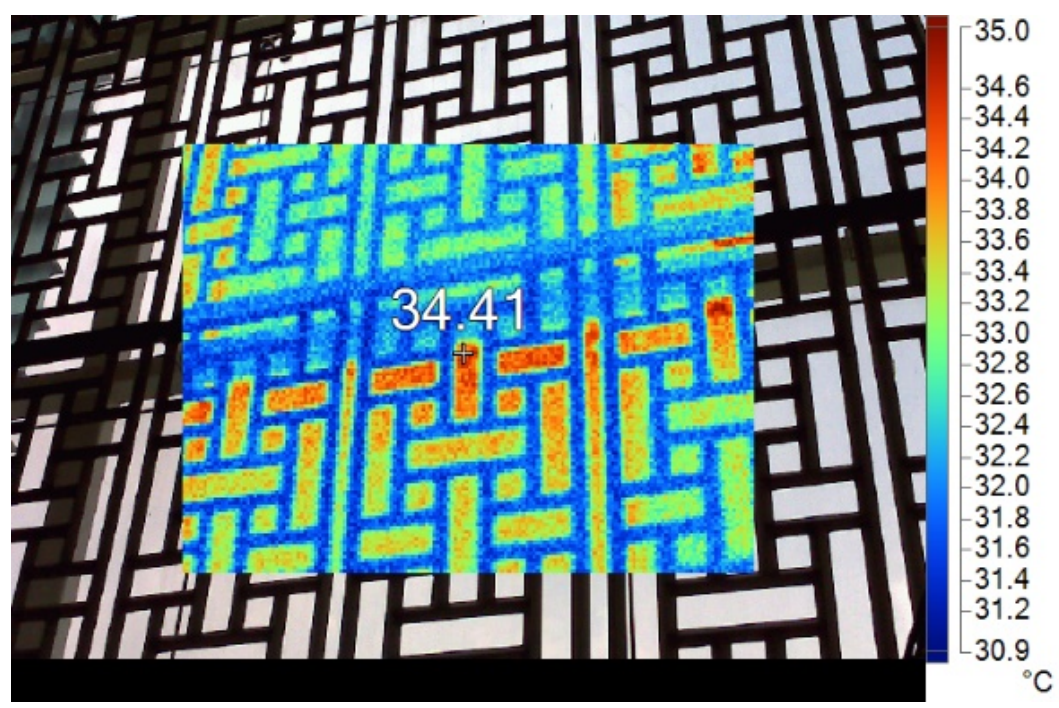

Figure 14. The surface temperature of the arabesque screen from inside the main prayer hall

The operable window was only provided at the lower part of the glass wall façade on each side of the main prayer hall. There was no curtain or blind provided on the window, therefore, allowing heat radiation through the clear glass into the space. Figure 15 shows the thermal image of the operable window which showed a higher temperature of the window frame than the clear glass panel itself. This shows that the clear glass had a thermal transfer value that was lower than the aluminium window frame. Figure 16 shows the internal view of the indoor surfaces which had different types of architectural finishes. Each building finished material that was chosen for the mosque had a thermal impact on the indoor space temperature. The indoor thermal condition was primarily influenced by the air temperature as well as the mean radiant temperature [33]. 


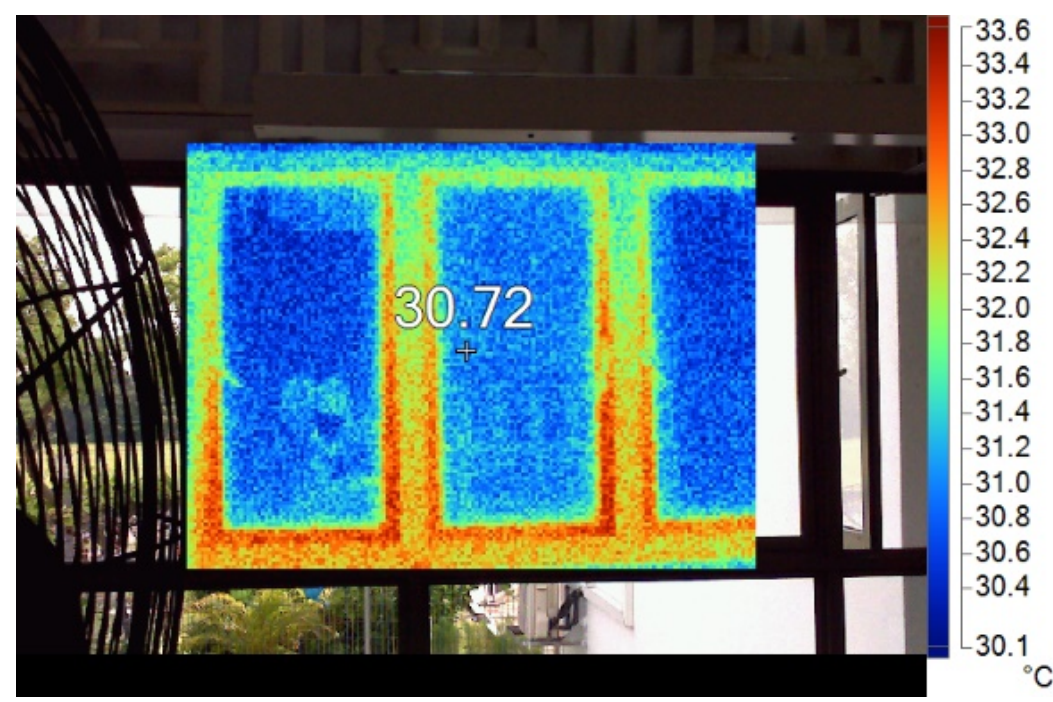

Figure 15. Surface temperature of single glass pane operable window from inside the main prayer hall

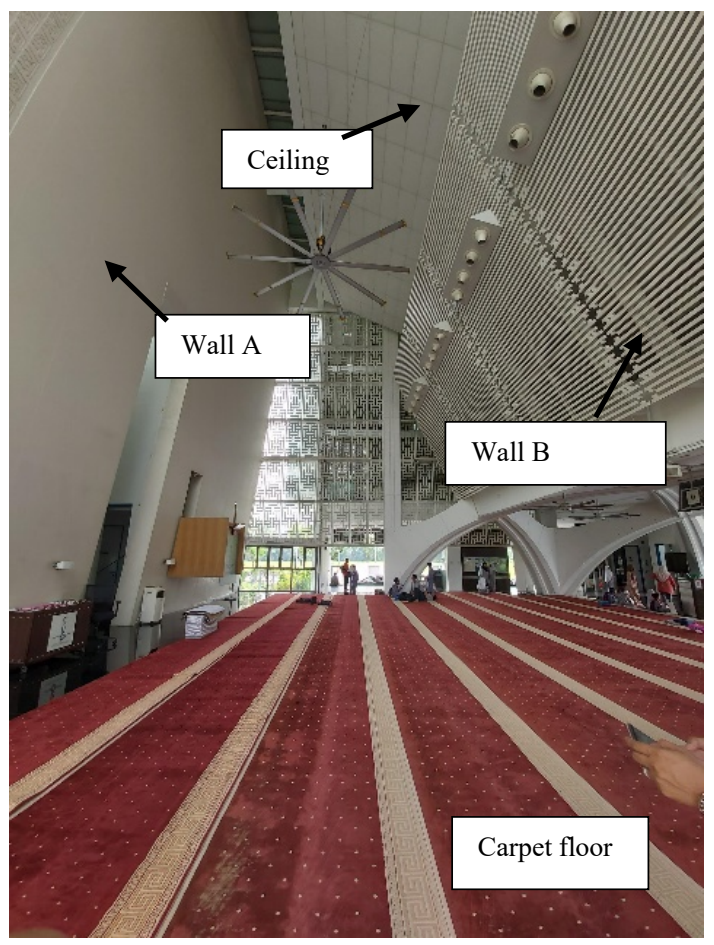

Figure 16. Internal wall and floor surface of the prayer hall. Prayer hall equipped with large industrial ceiling fan.

Figure 17 shows the measured surface temperature for surfaces such as the wall, floor and ceiling of the main prayer hall. Table 5 summarizes the surface temperature of the indoor surface taken before noon time. 


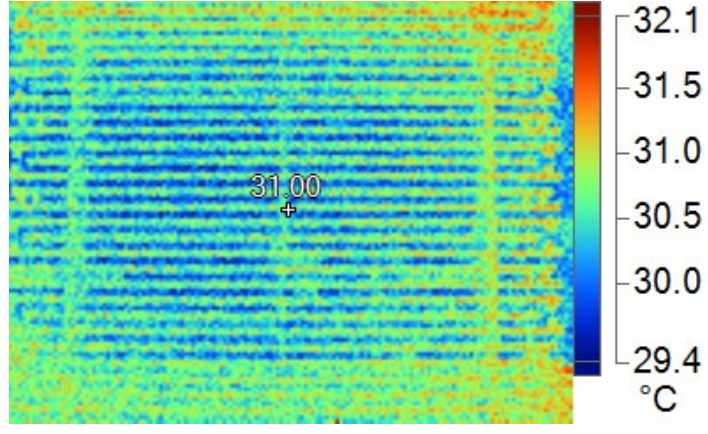

(a)

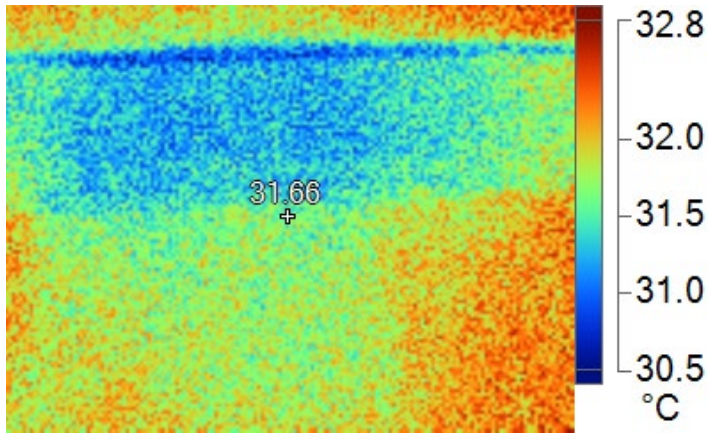

(c)

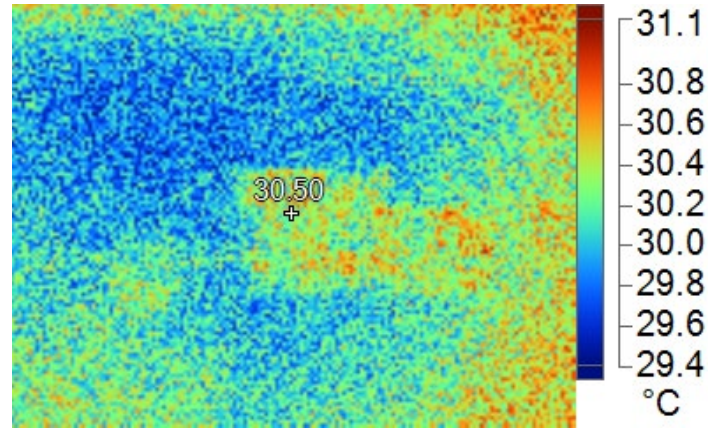

(b)

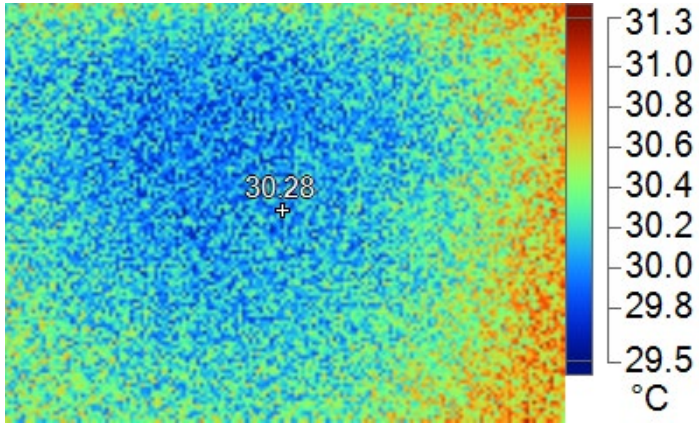

(d)

Figure 17. Measured surface temperature for (a) wall B, (b) wall A, (c) floor carpet surface temperature, and (d) ceiling surface temperature

Table 5. Measured indoor surface temperature

\begin{tabular}{|l|c|}
\hline Surface & Surface Temperature $\left({ }^{\circ} \mathbf{C}\right)$ \\
\hline Ceiling & 30.3 \\
\hline Wall A & 30.5 \\
\hline Wall B & 31.0 \\
\hline Floor carpet & 31.7 \\
\hline Glass wall & 34.4 \\
\hline Glass window & 30.7 \\
\hline
\end{tabular}

The floor was covered with carpet that had good resistance to heat transfer. Therefore, the cooling effect of the floor might not be apparent. The use of a glass wall on both sides of the prayer hall also caused the floor to be subjected to outdoor long-wave and short-wave heat radiation. The carpet was made of fabric that tended to absorb and retain heat, therefore, resulting in a higher temperature value. The uncarpeted cooler floor would otherwise contribute to lower radiant temperature which would influence the room air temperature. 
The indoor air temperature and relative humidity $(\mathrm{RH})$ of the main prayer hall were also measured as both parameters had a significant influence on the occupants' thermal comfort. Figure 18 shows the air temperature and RH reading from a datalogger that was located inside the prayer hall. The figure clearly shows how the indoor thermal condition of the main prayer hall mimicked the outdoor diurnal temperature. This effect was due to the doorless unobstructed opening which formed the main and side entrances to the main prayer hall that allowed the free airflow movement in and out of the building. The highest temperature recorded during the survey in the prayer hall was about $31^{\circ} \mathrm{C}$ during fine clear weather and the lowest recorded was about $27^{\circ} \mathrm{C}$. The mosque indoor thermal condition was contrary to a typical enclosed space with heavy mass construction type which tended to delay the peak indoor temperature for several hours by storing the heat in the mass and re-radiate the heat back to the space at night [31].

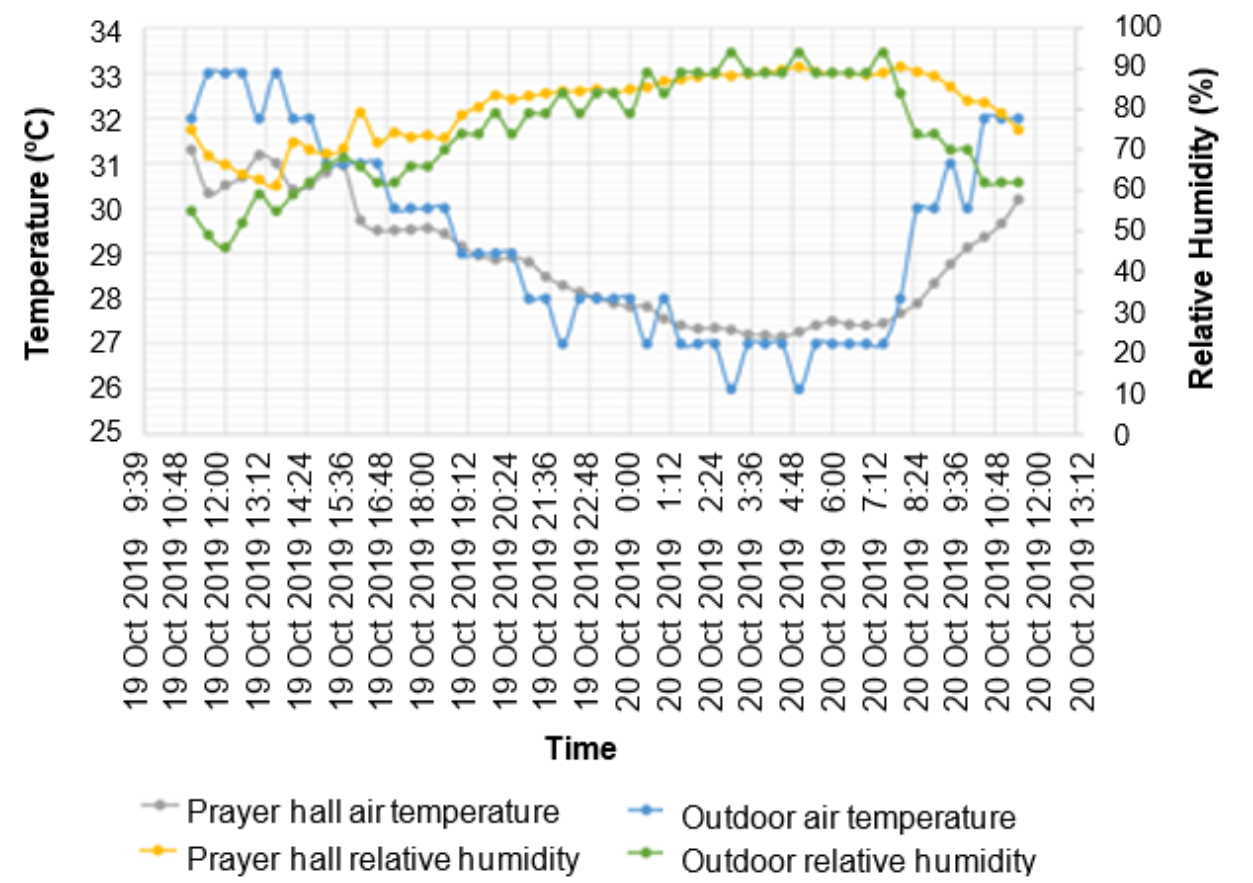

Figure 18. Measured indoor and outdoor air temperature and relative humidity

Another important climatic data that had a significant influence on the occupants' comfort was the air flow movement. A handheld air flow meter was used to measure the air movement in and around the main prayer hall. Local daily outdoor wind speed data was sourced from the local weather station data retrievable from an online weather report. Given the measured data such as the indoor air temperature, air humidity, airspeed and surface temperature, it was, therefore, possible to calculate the PMV value of the main prayer hall. A web-based PMV calculator such as the CBE thermal comfort tool was used to carry out thermal comfort calculation according to ASHRAE Standard 55-2017. For this purpose, if PMV calculation the metabolic rate was taken as 1 (met) while the clothing level was taken as 0.6 (clo). Figure 19 shows the calculated PMV value of the main prayer hall without occupant control air speed (fan not in operation). The highest PMV calculated was about 1.3 and the lowest PMV was 0.2 . The indoor air flow movement was entirely influenced by the outdoor air movement which was between $0.5-1.2 \mathrm{~m} / \mathrm{s}$ throughout the day. The PMV under this condition was slightly outside of the acceptable thermal comfort range. However, when the indoor fan was operated during prayer time, it provided air movement up to $6 \mathrm{~m} / \mathrm{s}$. This increased wind speed greatly improved the PMV value in the main prayer hall as shown in Figure 20. It was obvious that occupant local control of air speed greatly influenced the PMV level in the building. Building occupants would find thermal 
comfort in the main prayer hall provided there was air movement as shown in Table 6. Occupants thermal responses in this case depended greatly on the outdoor condition and with certain control of air speed.

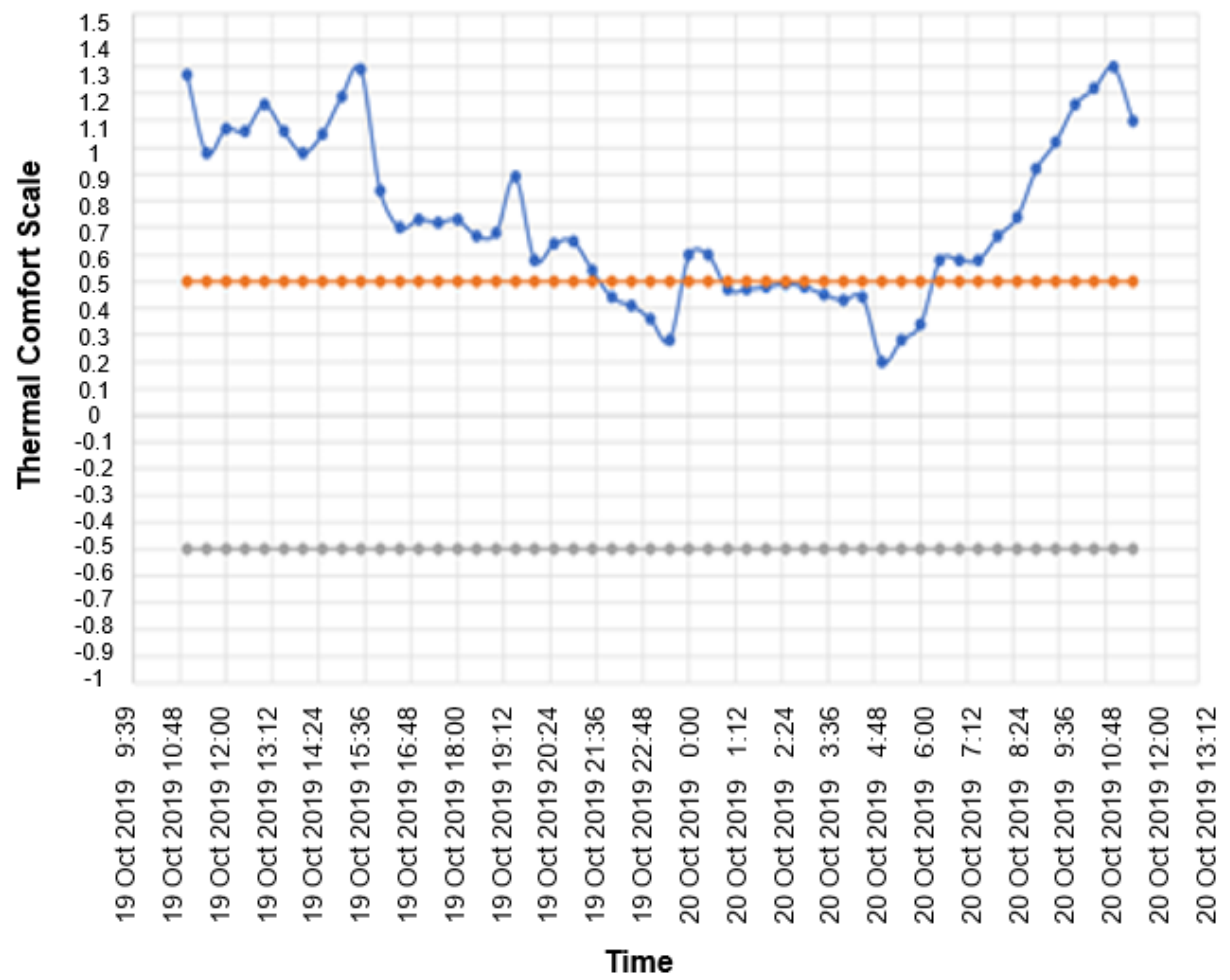

Figure 19. Calculated PMV for prayer hall without occupant control air speed $(0.5-1.2 \mathrm{~m} / \mathrm{s})$ throughout the day

Table 6. Air speed required to achieve at least 0.5 PMV at prayer hall during prayer time

\begin{tabular}{|c|c|c|}
\hline Prayer time & $\begin{array}{c}\text { Required occupant } \\
\text { control air speed } \\
\text { m/s }\end{array}$ & PMV \\
\hline Zohor & $3.5-4.0$ & 0.5 \\
\hline Asar & $1.2-1.7$ & 0.5 \\
\hline Maghrib & $0.9-1.1$ & 0.5 \\
\hline Isyak & $0.9-1.1$ & 0.5 \\
\hline Fajr & $0.4-0.5$ & 0.5 \\
\hline
\end{tabular}

The adaptive chart as shown in Figure 21 reveals the recorded operative temperature of the main prayer hall which was still generally within the acceptable range of operative temperature according to the adaptive model comfort zone for naturally conditioned spaces. The acceptable limits increased up to $2.2^{\circ} \mathrm{C}$ due to increasing air speed above $0.3 \mathrm{~m} / \mathrm{s}$ and up to $1.2 \mathrm{~m} / \mathrm{s}$ (ASHRAE, 2013). While many passive and green features had been integrated into the design and construction of the Assyafaah Mosque that managed to bring the main prayer hall to an acceptable thermal condition, some 
improvements still can be considered and implemented. A summary of some measures or actions that can be taken to further improve the indoor thermal condition especially during the hottest period of the day is included in the appendix.

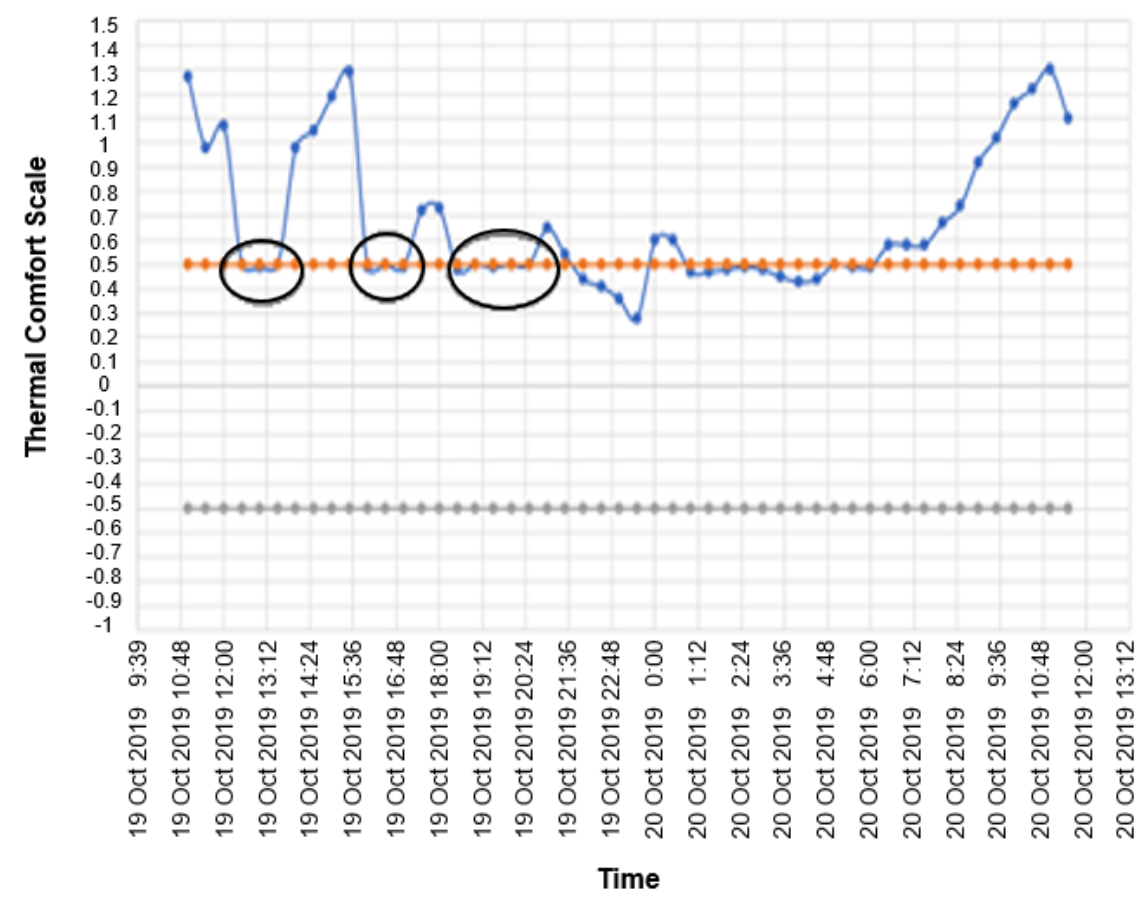

Figure 20. Calculated PMV for prayer hall with occupant control air speed $(1-4 \mathrm{~m} / \mathrm{s})$ during prayer time (highlighted in the circle)

One measure that may have a significant impact on the indoor surface temperature is to have vegetated roofing on top of the building open roof slab. The building open flat roof is shown in Figure 22. Installing a vegetated roof or green roof will benefit the building as well as the environment such as reduced water runoff, provision of natural air treatment, and buffer creation between ambient temperature and roof insulation which can reduce indoor surface temperature change as well as added protection to the roof membrane system itself from UV and thermal shock stress. 


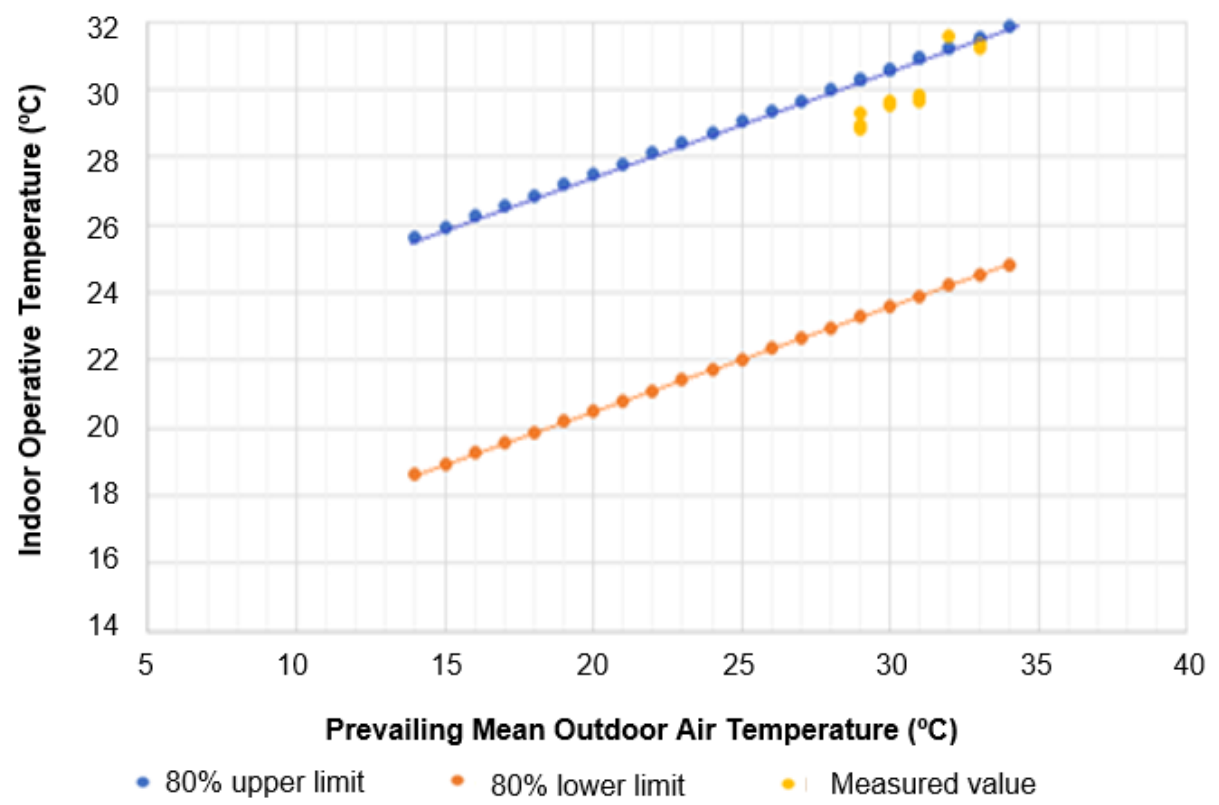

Figure 21. The operative temperature in prayer hall (during afternoon prayer time) against acceptable operative temperature range in naturally conditioned space

The proposed actions listed above will improve the current thermal condition of the building to some degree particularly the main prayer hall. It is generally accepted that some parameter is beyond the occupant control such as the outdoor environment factor-like outdoor air temperature, humidity and radiation from the sun. However, personal control that is independent of the environment such as clothing and local control of airspeed will regulate their comfort and adjust to the personal thermal environment.

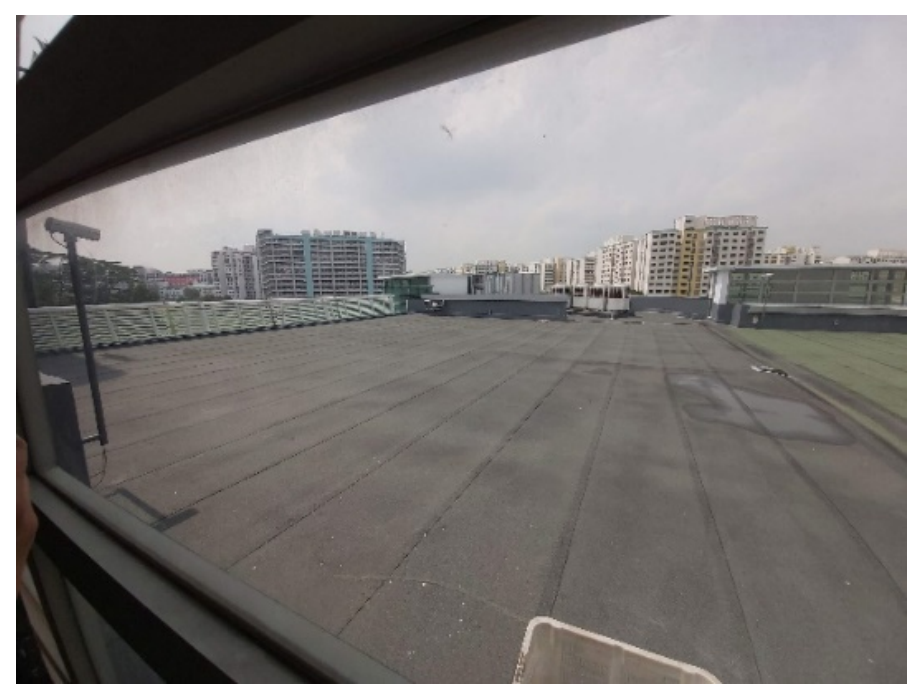

Figure 22. A roof garden or vegetated roof could be installed on a flat concrete roof to improve indoor

\section{Conclusion} heat temperature 
Assyafaah Mosque design and construction had taken into account several green designs and passive strategies to achieve an acceptable thermal environment condition with provisions to occupant control air speed. Some additional passive and active measures can be implemented to further improve the thermal condition of the building particularly the main prayer hall by applying water, air and ground as a natural heat sink.

\section{Acknowledgements}

The authors would like to thank Universiti Kebangsaan Malaysia, Islamic Religious Council of Singapore and Assyafaah Mosque for their contribution and support.

\section{References}

[1] Roberts, T. (2016). We Spend 90\% of Our Time Indoors. Says Who?. Building Green.

[2] Nizarudin, N. D. (2016). Spatial and sociocultural aspects of urban mosque open spaces in Kuala Lumpur, Malaysia: A mixed-method approach. Environment-Behaviour Proceedings Journal, 1(2), 43-51. https://doi.org/10.21834/e-bpj.v1i2.254

[3] Puteh, M., Ibrahim, M. H., Adnan, M., Che'Ahmad, C. N., \& Noh, N. M. (2012). Thermal comfort in classroom: constraints and issues. Procedia-Social and Behavioral Sciences, 46, 1834-1838. https://doi.org/10.1016/j.sbspro.2012.05.388

[4] Haraty, H. J. S., \& Utaberta, N. (2019). Contemporary trends of research and writing on mosques design: Analysis of the most recent publications. International Journal of Engineering \& Technology, 8(1.9), 528532. ISSN: $2227-524 X$

[5] Aziz, A. (2016). Execution of contemporary Islamic architecture through design: the cyberjaya green platinum mosque project in Malaysia. WIT Transactions on The Built Environment, 159, 11-22. DOI: 10.2495/IHA160021

[6] Deuble, M. P., \& de Dear, R. J. (2014). Is it hot in here or is it just me? Validating the post-occupancy

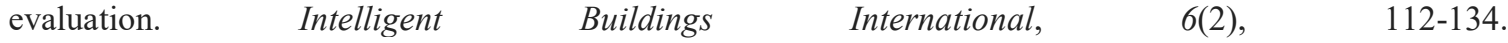
https://doi.org/10.1080/17508975.2014.883299

[7] Daghigh, R., Adam, N. M., Sopian, K., \& Sahari, B. B. (2009). Thermal comfort of an air-conditioned office through different windows-door opening arrangements. Building Services Engineering Research and Technology, 30(1), 49-63. doi: 10.1177/0143624408099448.

[8] Yang, W., \& Zhang, G. (2008). Thermal comfort in naturally ventilated and air-conditioned buildings in humid subtropical climate zone in China. International Journal of Biometeorology, 52(5), 385-398. https://doi.org/10.1007/s00484-007-0133-4

[9] Saeed, S. A. R. (1996). Thermal comfort requirements in hot dry regions with special reference to Riyadh part 2: for Friday prayer. International Journal of Ambient Energy, 17(1), 17-21. https://doi.org/10.1080/01430750.1996.9675211

[10] Kim, J., \& De Dear, R. (2012). Impact of different building ventilation modes on occupant expectations of the main IEQ factors. Building and Environment, 57, 184-193. https://doi.org/10.1016/j.buildenv.2012.05.003

[11] Healey, K. (2014). Measurement and interpretation of thermal comfort in a highly adaptive mixed-mode building. Architectural Science Review, 57(3), 207-214. https://doi.org/10.1080/00038628.2013.868782

[12] Ji, X. L., Lou, W. Z., Dai, Z. Z., Wang, B. G., \& Liu, S. Y. (2006). Predicting thermal comfort in Shanghai's non-air-conditioned buildings. Building Research and Information, 34(5), 507-514. https://doi.org/10.1080/09613210600722511

[13] Ibrahim, S. H., Baharun, A., Nawi, M. N. M., \& Junaidi, E. (2014). Assessment of thermal comfort in the mosque in Sarawak, Malaysia. International Journal of Energy and Environment, 5(3), 327-334. ISSN 2076-2909

[14] Bakhlah, M. S., \& Hassan, A. S. (2012). The study of air temperature when the sun path direction to Ka'abah: with a case study of Al-Malik Khalid Mosque, Malaysia. International Transaction Journal of Engineering, Management \& Applied Sciences \& Technologies, 3(2), 185-202. ISSN 2228-9860

[15] Al-Homoud, M. S., Abdou, A. A., \& Budaiwi, I. M. (2009). Assessment of monitored energy use and 
thermal comfort conditions in mosques in hot-humid climates. Energy and Buildings, 41(6), 607-614. https://doi.org/10.1016/j.enbuild.2008.12.005

[16] Al Anzi, A., \& Al-Shammeri, B. (2010, January). Energy saving opportunities using building energy simulation for a typical mosque in Kuwait. In Energy Sustainability, 43956, 383-391. https://doi.org/10.1115/ES2010-90478

[17] Budaiwi, I. M. (2011). Envelope thermal design for energy savings in mosques in hot-humid climate. Journal of Building Performance Simulation, 4(1), 49-61. https://doi.org/10.1080/19401491003746639

[18] Rasdi, M. T. M., \& Utaberta, N. (2012). The design of Mosques as community development centers from the perspective of the Sunna and Wright's organic architecture. Journal of Islamic Architecture, 1(1). https://doi.org/10.18860/jia.v1i1.1710

[19] Ismail, A. S., \& Rasdi, M. T. M. (2010). Mosque architecture and political agenda in twentieth-century Malaysia. The Journal of Architecture, 15(2), 137-152. https://doi.org/10.1080/13602361003791051

[20] Shaaban, A. (2014). Dh20-million green mosque opens in Dubai. Khaleej Times. https://www.khaleejtimes.com/nation/general/dh20-million-green-mosque-opens-in-dubai (accessed Jul. 20, 2014).

[21] BBC. (2019). Eco mosque opens for prayers in Cambridge. BBC News. https://www.bbc.com/news/ukengland-cambridgeshire-48044025 (accessed Apr. 24, 2019).

[22] Guardian. (2016). Morocco to gives 600 mosques a green makeover. https://gulfnews.com/world/mena/morocco-to-give-600-mosques-a-green-makeover-1.1891314 (accessed Sep. 05, 2016).

[23] M. Taylor, M. (2017). Indonesia unveils plan to roll out 1,000 eco-mosques by 2020 Jakarta, Dec. 16, 2017.

[24] Noman, F. G., Kamsah, N., \& Kamar, H. M. (2016). Improvement of thermal comfort inside a mosque building. Jurnal Teknologi, 78(8-4). https://doi.org/10.11113/jt.v78.9579

[25] ASHRAE. (2014). Chapter 14 . Climatic Design Information, in ASHRAE Handbook Fundemental, 2014th ed., Atlanta: ASHRAE, 1-43.

[26] Lau, S. S. Y., Zhang, J., \& Tao, Y. (2019). A comparative study of thermal comfort in learning spaces using three different ventilation strategies on a tropical university campus. Building and Environment, 148, 579-599. https://doi.org/10.1016/j.buildenv.2018.11.032

[27] Windfinder (2000). Yearly wind and weather averages for Singapore Changi Airport. https://www.windfinder.com/windstatistics/singapore_changi (accessed Oct. 29, 2019).

[28] Metereological Service Singapore (MSS). (2019). Climate of Singapore. http://www.weather.gov.sg/climate-climate-of-singapore/ (accessed Oct. 20, 2019).

[29] Brager, G. S., \& De Dear, R. J. (1998). Thermal adaptation in the built environment: a literature review. Energy and buildings, 27(1), 83-96. https://doi.org/10.1016/S0378-7788(97)00053-4

[30] International Organisation for Standardization. (2005). Ergonomics of the Thermal Environment: Analytical Determination and Interpretation of the Thermal Comfort Using Calculation of the PMV and PPD Indices and Local Thermal Comfort Criteria. ISO.

[31] Baker, N. V. (1987). Passive and low energy building design for tropical island climates. Commonwealth Secretariat.

[32] Imran, M. S., Baharun, A., Ibrahim, S. H., \& Abidin, W. A. W. Z. (2017). Investigation of earth tube system application in low income building in Kuching, Sarawak. Journal of Engineering Science and Technology, 12(6), 1433-1445.

[33] Tang, C. K., \& Chin, N. (2013). Building energy efficiency technical guideline for passive design. Public Works Department Malaysia, Kuala Lumpur. 


\section{Appendix}

Proposed measures to further improve the thermal condition in the main prayer hall of Assyafaah mosque

\begin{tabular}{|c|l|l|}
\hline No. & Proposed Measure & Impact \\
\hline 1 & Low e glazing & Reduce heat transfer rate through window glazing \\
\hline 2 & $\begin{array}{l}\text { Vegetated roof or vertical } \\
\text { plant }\end{array}$ & $\begin{array}{l}\text { Improve SRI of flat roof and reduce water runoff as well as } \\
\text { reducing indoor heat gain through roof and walls }\end{array}$ \\
\hline 3 & Double glazing for window & Reduce solar heat gain \\
\hline 4 & Evaporative cooling system & $\begin{array}{l}\text { Generate cooling effect from convection and evaporative cooling } \\
\text { of water }\end{array}$ \\
\hline 5 & Water fountain or mini pool & $\begin{array}{l}\text { Presence of a water body that absorbs heat and provides a cooling } \\
\text { effect }\end{array}$ \\
\hline 6 & More landscape and trees & Shading and cooling effect from evapotranspiration of plants \\
\hline 7 & Water spray on glazing & Reduce heat gain through glazing \\
\hline 8 & Water misting at the entrance & Provide cooling effect from evaporation \\
\hline 9 & $\begin{array}{l}\text { Air well for stack effect } \\
\text { openings }\end{array}$ \\
\hline 10 & $\begin{array}{l}\text { Rainwater harvesting and } \\
\text { using the flat roof as } \\
\text { catchment }\end{array}$ & $\begin{array}{l}\text { Supply water for landscaping demand and water spraying on } \\
\text { glazing as well as cool roof effect }\end{array}$ \\
\hline 11 & $\begin{array}{l}\text { Solar roof along a driveway } \\
\text { or flat roof }\end{array}$ & $\begin{array}{l}\text { Provide shading on roof or road pavement and further reduce heat } \\
\text { island effect as well providing an alternative energy source for } \\
\text { building }\end{array}$ \\
\hline 12 & Cool drinking water dispenser & Reduce body temperature \\
\hline 13 & $\begin{array}{l}\text { Operable window screen or } \\
\text { curtain }\end{array}$ & Reduce solar heat gain \\
\hline 14 & $\begin{array}{l}\text { Indoor thermal comfort } \\
\text { monitor }\end{array}$ & For monitoring purpose and corrective measures when necessary \\
\hline
\end{tabular}

